\title{
Perubahan Pola Serotipe Pasien Demam Berdarah Dengue pada tahun 2014, 2016, dan 2018 di Area Lahan Basah
}

Edi Hartoyo, Lina Purnamasari

Departemen Ilmu Kesehatan Anak Fakultas Kedokteran Universitas Lambung Mangkurat Rumah Sakit Umum Daerah Ulin, Banjarmasin

Latar belakang. Dengue adalah infeksi virus akut dengan 4 serotipe virus. Penelitian seroprevalensi pada anak di Indonesia menunjukkan terdapat perubahan pola serotipe dengue dari berbagai daerah di Indonesia.

Tujuan. Mengetahui apakah ada perubahan pola serotipe pasien DBD pada tahun 2014, 2016, dan 2018 di area lahan basah di Kalimantan Selatan.

Metode. Penelitian epidemiologi ini melibatkan 145 pasien anak di bawah 18 tahun yang dirawat di RS Ulin pada tahun 2014 , 2016 dan 2018 dan didiagnosis DBD oleh dokter spesialis anak berdasarkan tanda klinis, darah lengkap, dan serologi (IgM, IgG dengue). Sampel darah juga diperiksa untuk jenis serotipe dengan metode RT-PCR.

Hasil. Serotipe dengue pada tahun 2014 terbanyak adalah DENV-2 (38\%), diikuti oleh DENV-3 (30\%), DENV-4 (24\%), DENV1 (8\%); pada 2016 DENV-4 (35\%), DENV-2 (29\%), DENV-3 (21\%), DENV-1 (15\%); pada 2018 DENV-3 (39\%), DENV-4 (29\%), DENV-2 (23\%), DENV-1 (9\%).

Kesimpulan. Terdapat perubahan pola dominasi serotipe dengue di area lahan basah dari DENV-2 (2014), DENV-4 (2016) menjadi DENV-3 (2018). Sari Pediatri 2020;22(3):160-3

Kata kunci: demam berdarah dengue, serotipe dengue, DENV

\section{Changes Serotype Pattern of Dengue Hemorrhagic Fever Patients in 2014, 2016 and 2018 in Wetlands area South of Kalimantan}

Edi Hartoyo, Lina Purnamasari

Background. Dengue is an acute viral infection with 4 viral serotypes. Seroprevalence research on children in Indonesia shows that there are changes in dengue serotype patterns from various regions in Indonesia.

Objective. Determine whether there has been a change in the serotype pattern of DHF patients in 2014, 2016 and 2018 in wetland areas. Method. This epidemiological study involved 145 pediatric patients under 18 years of age who were hospitalized at Ulin Hospital in 2014, 2016 and 2018 and diagnosed with dengue by pediatricians based on clinical signs, complete blood count and serology (IgM, IgG dengue). The blood sample is checked for RT-PCR.

Result. The most dengue serotypes in 2014 were DENV-2 (38\%), followed by DENV-3 (30\%), DENV-4 (24\%), DENV-1 (8\%); in 2016 DENV-4 (35\%), DENV-2 (29\%), DENV-3 (21\%), DENV-1 (15\%); in 2018 DENV3 (39\%), DENV4 (29\%), DENV2 (23\%), DENV1 (9\%).

Conclusion. There is a change in the dominance pattern of dengue serotypes in wetland areas from DENV-2 (2014), DENV-4 (2016) to DENV-3 (2018) in wetland areas of South Kalimantan. Sari Pediatrí 2020;22(3):160-3

Key words: dengue hemorrhagic fever, dengue serotype, DENV

Alamat korespondensi: Edi Hartoyo. Departemen Ilmu Kesehatan Anak Fakultas Kedokteran Universitas Lambung Mangkurat Rumah Sakit Umum Daerah Ulin, Banjarmasin. Email: edihartoyo@yahoo.com 
I nsiden infeksi dengue di dunia masih tinggi sekitar 390 juta infeksi dengue per tahun. ${ }^{1}$ Di Indonesia, insiden demam berdarah dengue (DBD) pada tahun 2018 adalah 24,73 per 100.000 penduduk dengan angka kematian 0,7\%. Di area lahan basah seperti Kalimantan Selatan insiden 47,84 per 100.000 penduduk dengan angka kematian $0,75 \%{ }^{2}$

Virus dengue terdiri dari 4 serotipe (DENV-1 hingga DENV-4). ${ }^{3}$ Individu dapat terinfeksi lebih dari satu serotipe dengue. Infeksi sekunder dengan serotipe berbeda bisa menjadi lebih lebih berat (teori sekunder infeksi) dibandingkan infeksi primer. Serotipe dengue tertentu berkaitan dengan peningkatan keparahan infeksi sekunder. Infeksi DENV-2 dan DENV-3 diteliti dapat menginduksi respon sitokin total yang lebih tinggi, termasuk TNF- $\alpha$ dan IFN- $\gamma$, dibandingkan dengan serotipe lainnya. ${ }^{4}$

Pada beberapa negara di dunia terjadi perbedaan dominasi serotipe dengue. Pada penelitian di Brazil tahun 2012-2013, serotipe dengue terbanyak adalah DENV-3 dan DENV-1.5 Seroprevalensi di India tahun 2011-2014 terbanyak adalah DENV-2. ${ }^{6}$ Sementara di Malaysia tahun 2014-2017 adalah DENV-1.7 Beberapa daerah di Indonesia juga mengalami perubahan pola serotipe dengue. Serotipe dengue dominan di Jawa Timur dan Jawa Tengah pada tahun 2012 adalah DENV-1, sedangkan di Bali serotipe dominan adalah DENV-3. Penelitian seroprevalensi pada anak-anak di Indonesia pada tahun 2014 menunjukkan proporsi tertinggi adalah DENV-2, diikuti oleh DENV-1, DENV-3, dan DENV-4. ${ }^{3}$ Penelitian ini bertujuan untuk mengetahui adanya perubahan pola serotipe dengue pada pasien DBD tahun 2014, 2016, dan 2018 di area lahan basah, yaitu di Banjarmasin, Kalimantan Selatan.

\section{Metode}

Penelitian ini merupakan penelitian epidemiologi yang melibatkan 145 pasien anak berusia di bawah 18 tahun yang dirawat inap di RSUD Ulin Banjarmasin pada tahun 2014, 2016, dan 2018 yang terdiagnosis DBD oleh dokter spesialis anak. Diagnosis DBD berdasarkan kriteria klinis WHO tahun $1997,{ }^{1}$ pemeriksaan darah lengkap, dan serologi (IgM dan IgG Dengue). Sampel darah semua peserta penelitian diperiksa untuk mengetahui serotipe dengue dengan RT-PCR. Data dikumpulkan dari rekam medis RS Ulin Banjarmasin. Data serotipe dengue direkapitulasi per tahun lalu dibuat dalam bentuk diagram.

\section{Hasil}

Pada Tabel 1 tertera perubahan serotipe yang dominan tahun 2014, 2016, dan 2018 berturut turut adalah DENV-2, DENV-4, dan DENV-3. Terdapat perubahan distribusi dominasi serotipe tahun 2014, yaitu DENV-2, DENV-4 dan DENV-3.

Pada Tabel 1 dan Gambar 1 terlihat bahwa serotipe dengue pada tahun 2014 terbanyak adalah DENV2 (38\%), diikuti oleh DENV3 (30\%), DENV4

Tabel 1. Pola serotipe dengue tahun 2014, 2016, dan 2018

\begin{tabular}{lccc}
\hline Serotipe & $2014(\%)$ & $2016(\%)$ & $2018(\%)$ \\
\hline DENV-1 & $3(8)$ & $8(15)$ & $5(9)$ \\
DENV-2 & $14(38)$ & $15(29)$ & $13(23)$ \\
DENV-3 & $11(30)$ & $11(21)$ & $22(39)$ \\
DENV-4 & $9(24)$ & $18(35)$ & $16(29)$ \\
\hline Total & 37 & 52 & 56 \\
\hline
\end{tabular}
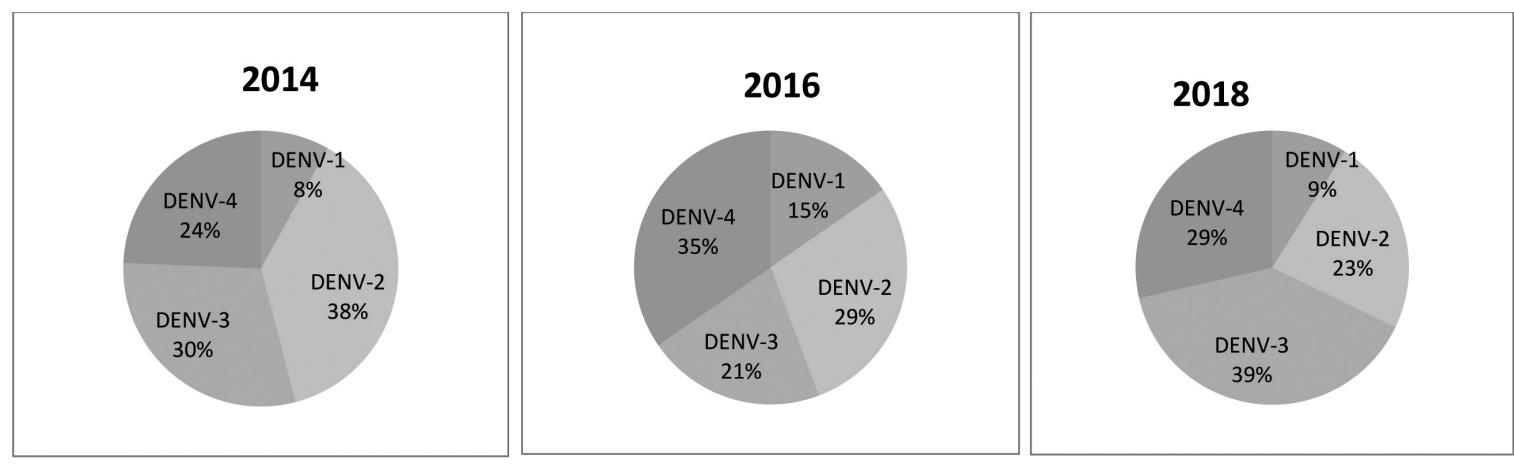

Gambar 1. Distribusi serotipe dengue 
(24\%), dan DENV1 (8\%). Pada tahun 2016 serotipe dengue terbanyak adalah DENV4 (35\%) diikuti DENV2 (29\%), DENV3 (21\%), dan DENV1 (15\%). Selanjutnya pada tahun 2018 , serotipe dengue terbanyak adalah DENV3 (39\%), DENV4 (29\%), DENV2 (23\%), dan DENV1 (9\%).

\section{Pembahasan}

Berdasarkan data temuan kami, terdapat perubahan pola serotipe dengue pada pasien DBD tahun 2014, 2016, dan 2018 di area lahan basah. Faktor risiko yang memengaruhi beratnya penyakit pada infeksi dengue, antara lain, infeksi sekunder atau primer, spesifik serotipe atau genotipe, jenis kelamin, umur dan status gizi. Perubahan serotipe tersebut bisa berpengaruh terhadap manifestasi klinis.

Perbedaan manifestasi klinis dengue berkaitan dengan infeksi serotipe tertentu. Penelitian seroprevalensi di Malaysia tahun 2014-2017 dilaporkan dengue tanpa warning sign banyak dijumpai pada infeksi DENV-1 dan DENV-3. Dengue dengan warning sign dan demam berdarah dengue berat terutama ditemukan pada infeksi DENV-2.7

Penelitian di Brazil dilaporkan bahwa sebagian besar demam berdarah dengue berat lebih sering disebabkan oleh serotipe DEN-2 dibandingkan DEN-1 dan DEN$4 .{ }^{8}$ Sementara penelitian di China antara tahun 20092013 melaporkan serotipe DENV-1 yang dominan. ${ }^{9}$ Sementara penelitian di negara negara Amerika Selatan lainnya, seperti Bolivia, Peru, Paraguay dan Equador, serotipe dominan berurut turut adalah DENV-3 (41,5\%), DENV-1(39,8\%), DENV-4(14,4\%) dan DENV-1 $(4,3 \%) .{ }^{10}$ Pada penelitian di Kuba pada tahun 1981 ditemukan penyebab terbanyak pada kasus demam dengue dan demam berdarah dengue pada anak dan dewasa terbanyak adalah serotipe DENV-1. Namun, setelah 20 tahun terjadi perubahan, yaitu pada tahun 1997. Pada saat itu terjadi outbreak DENV-2 yang paling dominan. Hal tersebut akan membawa konsekuensi terjadi banyak infeksi sekunder. ${ }^{1}$

Sementara itu, penelitian di Singapura tahun 2006-2008, keempat serotipe terdeteksi selama masa penelitian ini, dengan DENV-2 (80,5\%) yang berlanjut sebagai serotipe utama setelah wabah dengue besar pada tahun 2007. Secara teratur, terdeteksi juga DENV-1 (8,7\%) dan DENV-3 (8,2\%), sedangkan DENV-4 jarang ditemukan $(2,4 \%)$.
Di Indonesia, pernah terjadi perubahan dominasi serotipe (serotipe shift) di tahun 2000-an dari DENV3 ke DENV-1 dan DENV-2 dan terdapat dominasi dari beberapa serotipe di sebagian besar wilayah di Indonesia. Terdapat hal yang menarik, yaitu pergeseran serotipe cepat juga terjadi di negara lain di Asia Tenggara pada tahun 2000. Hal tersebut menunjukkan adanya fenomena regional. Perubahan secara cepat serotipe ini mungkin merupakan faktor paling signifikan yang berkontribusi terhadap tren peningkatan kejadian DBD di Indonesia antara tahun 2000 dan 2009. ${ }^{12}$

Kejadian yang terjadi di Banjarmasin Kalimantan Selatan, terjadi perubahan serotipe antara tahun 2014 dan 2016. Pada tahun 2014, serotipe didominasi DENV-3 dan DENV-3. Sementara pada tahun 2016 didominasi DENV-2 dan DENV-4. Hal tersebut menyebabkan terjadi outbreak dengan serotipe dominan DENV-3 dan DENV-4 pada tahun 2018. Kejadian ini mirip dengan kejadian di Indonesia pada tahun 2000 yang meyebabkan terjadi peningkatan kasus infeksi dengue pada tahun 2009.

Beberapa penelitian sebelumnya melaporkan bahwa perbedaan antara serotipe akan menyebabkan berbeda virulensi. Studi epidemiologi menunjukkan serotipe DENV-2 Asia lebih sering menyebabkan kasus DBD berat dibandingkan dengan serotipe Amerika. Penelitian invitro menunjukkan bahwa laju replikasi, baik di dalam makrofag yang diturunkan dari monosit manusia dan sel dendritik sebagai kerentanan vektor lebih tinggi untuk genotipe Asia. ${ }^{13}$ Terdapat temuan pula bahwa genotipe Asia dari DENV-2 memiliki tingkat replikasi yang sedikit lebih tinggi dalam nyamuk dan lebih pendek masa inkubasi ekstrinsik sehingga akan menyebabkan gejala klinis akan lebih berat dan terjadinya peningkatan jumlah kasus. ${ }^{14}$

Hal ini terjadi di Kalimantan Selatan, perubahan serotipe terjadi dari DENV-2 tahun 2014, ke DENV4 tahun 2016 dan DENV-3 pada tahun 2018, yang menyebabkan kenaikan kasus infeksi virus pada tahun 2018. Informasi mengenai seroprevalensi dapat berfungsi sebagai penanda dini untuk memprediksi berat ringannya klinis dengue. Penelitian seroprevalensi dapat digunakan untuk memprediksi outcome saat terjadi wabah dengue.

\section{Kesimpulan}

Terdapat perubahan pola dominasi serotipe dengue dari DENV-2 (2014), DENV-4 (2016) menjadi DENV-3 
(2018) dan menyebabkan kenaikan jumlah kasus di Kalimantan Selatan area lahan basah.

\section{Daftar pustaka}

1. World Health Organization. Dengue control - Epidemiology. Diunduh pada 25 September 2020Didapat dari: https://www. who.int/denguecontrol/epidemiology/en/.

2. Kementerian Kesehatan Republik Indonesia. Data dan informasi profil kesehatan Indonesia Tahun 2018. Jakarta: Kemkes RI; 2018.

3. Sasmono RT, Taurel AF, Prayitno A, dkk. Dengue virus serotype distribution based on serological evidence in pediatric urban population in Indonesia. PLoS Negl Trop Dis 2018;12:1-11.

4. Soo KM, Khalid B, Ching SM, Chee HY. Meta-analysis of dengue severity during infection by different dengue virus serotypes in primary and secondary infections. PLoS One 2016;11:4-14.

5. Santos TP, Cruz OG, da Silva KAB, dkk. Dengue serotype circulation in natural populations of Aedes aegypti. Acta Trop 2017;176:140-3.

6. Afreen N, Naqvi IH, Broor S, dkk. Evolutionary analysis of dengue serotype 2 viruses using phylogenetic and bayesian methods from New Delhi, India. PLoS Negl Trop Dis 2016;10:1-13.
7. Suppiah J, Ching SM, Amin-Nordin S, dkk. Clinical manifestations of dengue in relation to dengue serotype and genotype in Malaysia: A retrospective observational study. PLoS Negl Trop Dis 2018;12:1-20.

8. Creuza R, Karl-Heinz, Günter, Camila, Aline de Souza, Crispim Cerutti. Serotype influences on dengue severity: a cross-sectional study on 485 confirmed dengue cases in Vitória, Brazil BMC Infect Dis 2016;16:320-27.

9. Yongxia, Shufen, Xiaobo,Kui Zheng, Shuai Yuan, Jicheng Huang. Epidemiological and molecular characterization of dengue viruses imported into Guangzhou during 2009-2013. SpringerPlus 2016;5:1635-8.

10. Nicolas A, Caesar M, Carlos V, Tadeusz J, Alberto L, Tores. Correlation of serotype-spesific dengue virus infection with clinical manifestations. PLoS Negl Trop Dis 2012;6:1638-48.

11. Gupta E, Dar L, Kapoor G, Broor S. The changing epidemiology of dengue in Delhi, India. Virol J 2006;3:92-8.

12. Karyanti MR, Uiterwaal CS, Kusriastuti R, dkk. The changing incidence of dengue haemorrhagic fever in Indonesia: a 45-year registry-based analysis.BMC Infect Dis 2014;14:412.

13. Harapan H, Alice Michie, Mudatsir M, R. Tedjo Sasmono, Allison. Epidemiology of dengue haemorrhagic fever in Indonesia: Analysis of five decades data from the National Desesease Surviellance. BMC Res Notes. 2019; 12:350-358

14. Jose R, Mario R. Viral and epidemiological determinants of the invasion dynamic of novel dengue genotypes. PLoS Negl Trop Dis. 2010;4:11-19. 